\title{
The conditions of Hejaz in the Islamic era in Yemeni sources.
}

\author{
Ghalib Mahmoud Hamza, Assistant Lecturer Education Directorate of Babylon, \\ ghalib.mahmmod.2019@gmail.com \\ Nasur Abid Albaker Mahmoud, Nasurabid1988@gmail.com
}

\begin{abstract}
The research deals with the history of Al Hijaz in the Islamic era through what was mentioned by Yemeni sources and Yemeni researchers, which are considered one of the most important sections of the Arabian Peninsula in terms of both the religious and the economic aspects. The researcher found that $\mathrm{Al}$ Hijaz became independent state directly linked to the Khaliphate when the Khaliphate was transferred to the Umayyad state in in AD 664 / AH 14.

The Hijaz was divided into three administrative regions, the centers of which are Medina, Makkah and Ta'if, Makkah and Ta'if were gathered together for the ruler of the city. Makkah 696-683 / AH 3 is a center for him. The study necessitated its division into two topics, an introduction and a conclusion. The first topic dealt with the geography of the Hijaz and the political situations in the Hijaz until the emergence of the Emirate of Supreme (Alaween), while the second topic dealt with political life in the Hijaz from the beginning of the era of the Emirate of Alaween in the Hijaz in the seventeenth century .
\end{abstract}

Keywords: AlHijaz, Yemeni sources, Islamic era, Khaliphate.

Received: 08.12.2020 $\quad$ Accepted: 10.01.2021 $\quad$ Published: 03.02.2021

\section{INTRODUCTION}

Hejaz is considered one of the most important parts of the Arabian Peninsula in both religious and economic terms. It occupied great religious importance among the Arab countries because it was the home of the Islamic mission. The Prophet Muhammad (PBUH) was born in it and received the revelation. The Islamic call was launched from Hejaz. It links the Levant to Yemen, which had a great impact on the rise and prosperity of the commercial cities in Hejaz. When the caliphate was transferred to the Umayyad state in $41 \mathrm{AH} / 661$, Hejaz became a region that is directly linked to the state. Hejaz was divided into three administrative regions, the centers of which are Medina, Makah, and Taif. Makah and Taif were sometimes gathered for the governor of Medina and sometimes, each one has an administrative governor. Medina remained the center of the state of Hejaz in the Umayyad era except the era of Abdullah bin Al-Zubair (64-73 AH/ 683-692). He took Mecca as a center for his ruling.

\section{LITERATURE REVIEW}

The Hejaz region has retained its prestigious position among the regions of the Islamic State because it is the pole of the Islamic world and the kiblah of all Muslims as thousands of pilgrims from different Islamic world annually arrive to Hejaz. The Umayyad were very keen to follow the conditions of Hejaz. The status of Hejaz did not differ after the transfer of the caliphate to the Abbasids and the transfer of the center of ruling To Baghdad in Iraq. Hejaz remained a region that is linked to the capital Baghdad. The governors were sent to it from the princes of the Abbasids or from those who are closely related to the Abbasids. During the era of some of them, they gathered Hejaz and Yemen in one state centered in Mecca. The governor of Hejaz appointed a representative for him in Yemen. So, Hejaz had a Distinguished religious position among Muslims. Hejaz was associated with relations with other Arab countries, including Yemen. Hejaz gained the attention of all Arab researchers, whether from the people of Hejaz themselves or from other Arab countries, especially Yemeni researchers. To find out what the researchers and Yemeni sources mentioned, the researcher conducted the present study, which sheds light on the history of Hejaz Through what was mentioned by those Yemeni sources and Yemeni researchers. The present study is divided into two sections. Section one tackles the geography of Hejaz and the political situation until the emergence of the Alawite Emirate in Hejaz. Section two deals with political life in Hejaz from the beginning of the era of the Alawite Emirate in Hejaz until the end of the seventh century AH. Because of the scarcity of studies about 
Yemeni sources, the researcher has many difficulties due to the lack of information about Hejaz in the Yemeni sources. Most Yemeni sources did not mention the events of Hejaz except with regard to their events that have a link to the events in Yemen. There are some important Yemeni sources that did not mention any of the Hejaz events except mentioning the Hajj season. The most important sources is the book of behavior in the classes of scholars and kings by Al-Jundi Muhammad bin Yusuf bin Yaqoub, the book of the mirror of Paradise and the lessons of ages in knowing the events of time by Abu Muhammad Afif Al-Din Abdullah bin Asaad bin Ali, the book of pearly contracts in the history of the Apostolic State by Al-Khazraji Ali bin al-Hassan Ibn Abi Bakr Ibn Al-Hassan, on which section two relied on. And the book of Gayat Al-Amani" in the news of AlQatrani by Yahya bin Al-Hussein bin Al-Qassim.

\section{Section One}

The conditions of Hejaz in the Yemeni sources until the emergence of the Alawiat Emirate.

Hejaz is located in the middle of the Arabian Peninsula. It is called the Arabian Peninsula because the Arabic language is all common. Hejaz is a mountainous region located in the northwestern part of the Arabian Peninsula. It extends from the borders of the Levant at Aqaba to a valley below Al-Surat in the sea where the land of Tihama begins. It is called Hejaz because it separates the Tihama Valley from Najd. It is said that Hejaz is called Hejaz because of the heat in it and its people detent in it from the enemy. Hejaz witnessed many wars, including the ungodly war between Qais Aylan and Kinana in which they decided to fight in the sacred months. So, it was called (the ungodly war). The Messenger Muhammad (PBUH) conquered Makah at the year (8 AH/ 629) and appointed Atab ibn Asid al-Umawi as its ruler. His ruling continued even during the reign of Abu Bakr al-Siddiq. In the era of the Umayyad state (41-132 AH/ 661-749), the Levant was taken as the center, and Damascus became the capital of the Islamic State. Hejaz became a region that is directly linked to the state. Hejaz was divided into three administrative regions, the centers of which are Medina, Makah, and Taif. Makah and Taif were sometimes gathered for the governor of Medina and sometimes, each one has an administrative governor. Medina remained the center of the state of Hejaz in the Umayyad era except the era of Abdullah bin Al-Zubair (64-73 AH/ 683-692). He took Mecca as a center for his ruling.

In (61 AH/ 680), Yazid sent to the ruler over Medina Al-Walid bin Utbah to take pledge of allegiance from the people. So, he sent to Al-Hussein bin Ali and Abdullah bin Al-Zubayr at night. He brought them together and said to them that they should pledge allegiance. But, they said that they do not pledge allegiance in secret, but pledge allegiance publically. So, they went back home. Exactly at that night, they went out to Mecca. Then, Al-Hussein stayed in Makah during the month of Sha'ban, Ramadan, Shawwal, and Thi AlQa'dah. He went out on the day of Al-Tarwiyah heading to Kufa. So, Ubaidullah bin Zyad bin Abeeh sent an army that met with Al-Hussein in Karbala. In (63 AH/ 682), the people of Medina revolted against Yazid. AlHaridhi Al-Yamani attributes the reason for this revolution to his lack of religion. So, he sent them an army under the leadership of Muslim bin Uqba. A battle broke out between them in Hurra. More than three hundred and a number of companions were killed. The dead on both sides is estimated at (6000). The city was plundered and became subject to the order of Muslim for three days. Ibn Ali describes the actions of Muslim bin Uqba with the people of Medina by stating that he ordered that the prisoners are boiled with iron. He called people to The pledge of allegiance that they are slaves to Yazid bin Muawiyah and whoever refuses to do so would be killed. One day, they brought him a teenager to pledge allegiance to Yazid. He was angry with him. He disavowed him and his parents. But, when he saw him, he shuddered, got up to him, and sat him next to him and said to him: "Ask me your needs". He did not intercede for anyone who offered the sword except to intercede for him. He said," This was not my opinion, but when I saw it, it filled my heart with horror".

In (64 AH/ 683), the Umayyad army, led by Al-Hosayn bin Namir Al-Sukuni, besieged Makah for Abdullah bin Al-Zubayr did not pledge allegiance to Yazid. The people of the Two Holy Sanctuaries pledged allegiance to Ibn al-Zubayr. Then, part of the Umayyad army pledged allegiance to Ibn al-Zubayr. When Ibn alZubayr called to himself and the people of Hejaz pledged allegiance to him, Abdullah bin al-Abbas and Muhammad ibn al-Hanafiyy refused saying: "We will not pledge allegiance to you until the country and the people come together. He threatened them. Abdullah bin Al-Zubayr built the Kaaba on the bases of Abraham (PBUH). He inserted the stone into the house. It was also cracked from the catapult and its roof was burned.

In (73 AH/ 692), Al-Hajjaj bin Yusuf Al-Thaqafi arrived to Makah to fight bin Al-Zubayr. He besieged him and set up a catapult on the Mount of Abu Qubais. The fighting lasted for months. When the siege on his companions was prolonged, they separated from him. So, he entered his mother Asma bint Al-Siddiq and told her that his companions had separated from him and that his opponents told him : If you wish, surrender 
yourself to Abdulmalik bin Marawan and you have security. He consulted her on that. She said to him: Oh, my son, if you are fighting for other than Almighty Allah, you will perish. If you are fighting for Almighty Allah, do not surrender yourself to the illiterate. So, he left her at that time until he met the armies of Abdulmalik at the top of Mecca and he fought them, but he was killed. Al-Hajjaj bin Yousuf Al-Thaqafi became the ruler of Hejaz. In (75 AH/ 694), Abdulmalik bin Marwan arrived at Makah and orated on the pulpit of the Prophet (PBUH) and ended Al-Hajj j's ruling over Hejaz.

In (87 AH/ 705), Al-Walid bin Abdulmalik appointed Omar bin Abdulaziz over Medina During the reign of Suleiman bin Abdulmalik, Khalid bin Abdullah Al-Qasri ruled Mecca and then, he was removed and Talha bin Dawood Al-Hadhrami was appointed. He was ordered to punish Khalid and beat him with a whip. When Omar bin Abdulaziz came, Abdulaziz bin Abdullah was the governor of Mecca. At the end of the Umayyad state, there were many owners of cabarets in the Two Holy Mosques, especially during the reign of Abdulaziz bin Omar bin Abdul Aziz. A group asked the governor to remove that. He ordered that singers should be removed from Medina. It seems that the conditions of Hejaz deteriorated in the late Umayyad state. In (130 AH/ 747), Abu Hamza al-Khariji, deputy of Abdullah bin Yahya, took control of Hadramout, Sanaa and Dhofar. They expelled the Umayyad ruler al-Qasim bin Omar al-Thaqafi. They seized Hejaz and killed the people of Qudayd, which is a location near Mecca and took control over Medina and stayed there for four months. Then, they went out to the Levant.

The Abbasids ruled Hejaz according to the same policy that the Umayyad followed. Hejaz remained a region that is linked to the capital, Baghdad, and governors were sent to it from the princes of the Abbasids or from those who are closely related to the Abbasids. Abu al-Abbas al-Saffah (132-136 AH/ 750-754) was the first Abbasid caliphate. He strengthened the Abbasids ruling and the consolidation of the pillars of their state. Therefore, he sought help from his brothers, cousins, and nephews so that none of his leaders or Abbasid preachers monopolize matters without them, on the one hand, and on the other hand, he wanted to transfer power gradually to the hands of members of the Abbasid family. Therefore, he appointed the closest, including his uncle Daoud bin Ali on Hejaz and Yemen.

In (144 AH/ 761), Abu Jaafar al-Mansur arrived to Hejaz. When he entered Medina, the people of Medina met him except Muhammad bin Abdullah bin al-Hassan bin al-Hassan bin Ali ibn Abi Talib (the pure soul) and his brother Ibrahim. That matter worried Al-Mansour. He felt that the survival of Muhammad, the pure soul, was a danger threatening the entity of his state. So, he worked to get rid of them. He arrested their father and imprisoned him with his family and they all died in prison. When Muhammad knew of the death of his father, he revolted with his followers whom al-Yafiee estimated to be (250) in Medina against The Abbasid Caliphate. They arrested the governor of Medina. He gave a speech and pledged allegiance from the people. The people of Medina willingly and unwillingly pledged allegiance to him. He told them that the reason for his revolution was the anger for Almighty Allah. They took over Mecca, Yemen, and the Levant. Al Mansour appointed his cousin Isa bin Musa to fight them. Al-Mansour said: I don't care which one of them kills the other. He said that because Isa was the crown prince after Al-Mansour according to the recommendation of Al-Saffah. It is said that Al-Mansur wanted to destroy him so that his son, Al-Mahdi, would take his place. Isa led four thousand fighters and promised them to fulfill their demands. Some of Muhammad's followers left him. They told him to march To Egypt. He refused and instead, he remained in Medina and deepened its trench. When Isa arrived to Medina, only a few group stayed with Muhammad. Isa offered him safety for him and his family if he surrendered. Muhammad refused. Then, Isa warned the people of Medina for days. Then, he crawled over Medina. The battle broke out. Muhammad was killed and Isa sent his head to Al-Mansour. Al-Haridhi describes Al-Mansur's relationship with the people of the Prophet's house by stating that Al-Mansur did what his brother Al-Saffah avoided. He made killing the people of the Prophet's family like Sunnah In the rest of the Abbasids. In (158-169 AH), Al-Mahdi became the ruler of Hejaz. In (160 $\mathrm{AH} / 776$ ), he headed for the Hajj. In the Two Holy Mosques, he divided the money and clothing that he took from Iraq. It is said that thirty thousand dirhams and hundred and fifty thousand garments were distributed.

In (167 AH/ 783), Al-Mahdi ordered an increase in the Mosque. He spent great money on that. Hussein bin Ali bin al-Hassan bin al-Hussein bin Ali appeared in Medina in (169 AH/ 785). Many people pledged allegiance to him and fought the Abbasid forces in Medina and killed its ruler Khalid bin Yazid. Then, he went out to Makah. Many people turned to him. Al-Hadi (170-169 AH/ 785- 786) ordered Muhammad bin Suleiman to take over the leadership of the army. The battle broke out on the day of Tarwiyah in a place called Fakh. The Abbasids attacked and killed Hussein bin Ali with one hundred of his companions. When Harun al-Rashid came, he gathered the states of Hejaz and Yemen to Muhammad bin Ibrahim al-Hashemi. So, he resided in Hejaz and sent his son al-Abbas to Yemen. 
In (198 AH/ 814), Al-Ma'mun made Ishaq bin Isa the ruler of Hejaz. Ibn Abdulmajeed mentions that Ishaq bin Musa bin Issa al-Hashemi was in Yemen. In (199 AH/ 815), he traveled to Hejaz when he knew of the appearance of Muhammad bin Ibrahim, known as Ibn Tabataba in Kufa. He seized it and sent a group of fighters towards Hejaz. So, they seized Hejaz and Mecca. He returned to Sana'a.

The conditions of Hejaz were disturbed. So, Muhammad bin Suleiman bin Dawood bin al-Hassan bin al-Hassan bin Ali bin Abi Talib revolted in Medina and seized it without fighting. Hussein bin Hassan bin Ali bin al-Hussein bin Abi Talib revolted in Mecca. He could control Mecca. Then, They pledged allegiance to Muhammad bin Jaafar al-Sadiq, who took control of Mecca and brought out Dawud bin Isa al-Hashemi, the governor of Mecca. Therefore, al-Ma'mun sent Isa bin Yazid al-Jaludi to him. When he reached Makah, Isa took Muhammad to al-Ma'mun in Khurasan, but he died on the way. Yemen was under the control of Ibrahim bin Musa bin Jaafar bin Muhammad bin Ali bin Al-Hussein bin Ali bin Abi Talib. Yazid bin Muhammad alMakhzoumi went to Yemen. When Muhammad bin Musa found out about him, he left Yemen heading to Hejaz. When Yazid bin Muhammad knew of that, he prepared for that and a battle broke out between them. So, Yazid was killed and his army was defeated. Al-Jundi states that Muhammad ibn Musa performed the Hajj in $200 \mathrm{AH}$ and overpowered Mecca.

In (212 AH/ 828), Abu Muhammad al-Qasim ibn Ibrahim Tabataba took control over Hejaz. The people of Medina and Mecca pledged allegiance to him. Al-Ma'mun and al-Mu'tasim tried to eliminate him, but they failed. He moved from Hejaz to the mount of Al-Rass outside Mecca and remained there until he died in (246 AH/ 860).

In (249 AH/ 863), Ismail bin Yusuf appeared. He was in Medina. He fought Ali bin Al Hussein bin Ismail over the endowment he had. He collected a group of Bedouins and went out with them to take money that had been carried to the Sultan from some cities and then went to Mecca, taking advantage of the weakness of the Abbasid authority in Baghdad Because of the dispute over the succession between AlMustaeen and al-Mu'taz and the Turkish interference in the affairs of the government. Ismail entered Makah and Jaafar bin al-Fadhl fled. And. Ismail's soldiers plundered his house and took control over it to take what was in the governor's treasuries and what was in the treasures of Kaaba. He prevented supplies from reaching Makah until the most of its people died of hunger and thirst. Then, he moved to Jeddah and prevented food from people and took the money of merchants and boat owners. The Abbasid state sent an army led by Muhammad bin Ahmed bin Isa and Isa bin Muhammad al-Makhzoumi. A battle in which 1200 pilgrims were killed and people were robbed. They fled to Makah. Ismail returned to Jeddah and then returned to Mecca and died there in (252 AH/ 866).

It seems that the interest of the Abbasid in Hejaz was limited to the Two Holy Mosques and the places leading to them as for the other regions. Therefore, they neglected their affairs. Because of the high prices and the difficulty of living, some tribes returned to cutting roads, especially the road between Makah and Jeddah. Ja 'far bin Al-Fadhl fought them. In (314 AH/ 927), the people of Mecca migrated to Taif and elsewhere for fear of danger.

In (317 AH/ 329), they entered Makah and attacked Abu Taher al-Qarmati on the day of Tarwiyah. They killed the pilgrims in the mosque and outside Mecca. The ruler of Mecca Ibn Muhareb went out with a group of honorable people. He killed them and threw some of their corpses in Zamzam. He uprooted the Black Stone and looted the round. It was taken to the city of Hajar in Bahrain and remained there until (339 AH/ 950). He killed 1700 people in the mosque. It is said that 13000 people were said to have been killed outside Mecca. 30000 women and boys were taken as captives in the same way. He stayed in Makah for six days, and no one did Hajj. The black stone remained in Hajar (22) years. It is said that 6000 people were killed in the mosque. Al-Ahdal states that who were killed in the Mosque are 2000 and about 10000 from other places in Makah. They opened the Kaaba and uprooted all the gold and silver on it. Ibn Ali states that Ubayd Allah al-Mahdi ordered him to return the stone to its place.

It seems that the Abbasid state was unable to protect the pilgrims as the administration of Hejaz was assigned to the governor of Egypt, Muhammad bin Tughj al-Akhshidi, who was a subordinate to the Abbasid state. Therefore, the sermon was held in Mecca to the governor of Egypt, Muhammad bin Tughj. When alRadi's brother came, he did not oppose this procedure, but he supported it by annexing the entire Hejaz to the Ikhchidis in (331 AH/ 942). The sermon was held for him in Makah and Medina. The Abbasid ruler-ship continued in the form of Al-Akhshidis (323-358 AH/ 924-968) until the Buyids took control over Baghdad in (334 AH/ 945). 


\section{Section two}

The conditions of Hejaz in the era of the Emirate of the Al-Ashraf.

In the second half of the fourth century $\mathrm{AH} /$ tenth century, Hejaz witnessed an increase in the influence of the Alawites from. Ruling dynasties appeared in Makah that all ended in their lineage to Musa bin Abdullah bin Musa bin Abdullah bin Al-Hassan bin Ali bin Abi Talib. Their loyalty was linked to the Fatimids, Ayyubids, Mamelukes, and the Abbasid state. Competition became between the Abbasid state and the Fatimid state over the subordination of Hejaz and the establishment of the sermon for them in Makah because it represents their sovereignty and legitimacy over the Islamic world. Ja 'far Ibn Al-Hassan Ibn Muhammad Ibn Musa Ibn Abdullah Ibn Musa Ibn Abdullah Ibn Al-Hassan Ibn Ali Ibn Abi Talib announced the sermon to AlMu izz Li Din Allah Al-Fatimid in (359 AH/ 969). He wrote to the deputy of Al-Muizz in Egypt who In turn, told Al-Muizz. Idris states that the princes used to come for Hajj during the days of Al-Mu'izz.

Then, his son Isa ruled until (384 AH/ 994). Then, his brother Abu al-Futuh al-Hasan ibn Jaafar departed from the obedience of the Fatimid state in (400 AH/ 1009) after declaring his independence in Makah and calling himself Al-Rashid. This was encouraged by the Minister of Ali bin Al-Hussein, who was angered by Al-Hakim for his actions that were contrary to the actions of the followers of the imams. Many Arabs responded to him after he gave them money and went out to the Levant, but these separated from him after the lack of money spent for them. He returned to Mecca and gathered people and disowned himself and disavowed his actions and sent a delegation to the Fatimid to apologize. He was returned as a prince of Makah and paid the donations. Abu Al-Fotouh was dismissed and his cousin Abu Al-Tayyib Dawud was appointed, but he returned to power three years later after returning his relationship with the state. He returned the sermon in Makah and continued until (430 AH/ 1038). His son Shukr succeeded until (453 AH/ 1061). Then, Abdullah took over after him.

It seems that he was a servant of Shukr. He narrated that the sons of al-Tayyib al-Hasaniyyas took over the Emirate of Mecca after Shukr. Then, the Emirate of Makah went after that to Ali bin Muhammad, the prince of the Sulayhid state in Yemen after Hejaz was annexed to him. Then, Muhammad bin Jaafar bin Muhammad bin Abdullah took over. In (462 AH/ 1069), he returned the Abbasid sermon in Hejaz and cut off the sermon to the Fatimids due to the drought and the plague that struck Egypt and nearly seized the valley of Egypt. Sultan Alp Arslan sent 30000 dinars to Muhammad bin Abi Hashem. But, Al-Mustansir sent gifts to the prince of Mecca. He returned the sermon to Al-Mustansir. That was in (467 AH/ 1074). Al-Qasim announced the cutting of the Abbasid sermon and declared his loyalty to the Fatimids, which forced the Abbasid to send a military campaign led by Isbeid, who was able to bring out Al-Qasim. But, al-Qasim came back and took control over Makah and expelled Asbheid in (487 AH/ 1094). He ruled and continued to circulate it with his brother Dawood for more than thirty years or more until the Emirate of Al-Hawashim ended and a new emirate began, which is the Emirate of Bani Qatada bin Idris. In (569 AH/ 1173), Salah Aldin and Yusuf bin Ayyub, the Sultan of the Ayyubid state arrived in Egypt, then to Mecca, and from there to Yemen. In (589 AH/ 1193), the ruler of Mecca, Dawood bin Isa bin Felitah bin Qasim bin Muhammad bin Abi Hashem al-Alawi alHusayni divided his emirate between him and his brother Makthar bin Issa. Once, he ruled and then his brother. The state of Bin Falitah ended after Abu Aziz Qatada ibn Idris al-Hasani defeated Mecca in 598 AH/ 1201. Ibn Ali mentions that the reason for the greed in the Emirate of Makah is what he narrated about the preoccupation of its princes, Al-Hawashim, the sons of his fleet With amusement. So, he prepared Qatadah to Mecca in a group of his people. They did not have the energy to meet him.

In (600 AH/ 1203), Makthar bin Isa returned to Mecca to fight Qatada. The battle ended with the victory of Qatada. It seems that the era of Qatada, which is the beginning of the rule of the third family of AlHassan family in Mecca, witnessed a struggle between them and Al-Ashraf in Medina on the one hand, and on the other hand, Makah witnessed unstable conditions due to the struggle between Banu Qatada themselves for power. Some of them sought help from The Ayyubids in Egypt. Some of them sought the help of the authorities in Yemen. In (601 AH/ 1204), battles occurred with Prince Salim bin Qasim, the prince of Medina. Qatada wanted to annex Medina to his mandate. Prince Salim was able to defeat Qatada after he sought the help of Sultan Issa bin al-Malik al-Adil Abu Bakr bin Ayyub, Sultan of Damascus, who sent him a strong army with which he was able to defeat Qatada, who withdrew to Makah. In (608 AH/ 1211), Qatada al-Sharif alHasani, the Prince of Mecca, looted the Iraqi pilgrims in Mina after he killed some of them because of the mystical killing of a member of the family of Prince Qatada in Mina, thinking that he was Prince Qatada. Qatada gathered the nobles, the slaves, and the people of Mecca and attacked the pilgrims. The people of Mecca plundered the pilgrims, but after the end of the Hajj season, Qatada sent a delegation to Baghdad 
headed by his son to apologize to the Abbasid for what happened. Hassan bin Qatada assumed the emirate of Mecca after the death of his father in (617 AH/) 1220). He was identified by the King of Al-Ashraf in (618 $\mathrm{AH} / 1221)$. Al-Hassan was the one who killed his father by suffocation or poison. This matter was revealed after King Masoud of Yemen ordered the king of Yemen when he took control over Hejaz after Al-Hassan to dig the grave of Qatada and burn him. They found An empty coffin in the grave . The people knew that Hassan was the one who killed him. He buried the coffin in the grave to conceal his command. Sultan Nuruldin Omar bin Ali became governor in Mecca by King Saud in (617 AH/ 1220) after heading to Hejaz to fight al-Hassan bin Qatada bin Idris. When he entered Makah, he ordered an end to the bloodshed and abuse. Al-Hassan was able to assemble his forces again and marched to Mecca, but Nuruldin Umar was able to defeat him again. In (629 AH/ 1231), Sultan Nuruldin, who was in Yemen, sent an army with the Sharif Rajeh bin Qatada with a large treasury with them. They reached Makah and besieged Sharif Rajah. The people of Mecca broke and killed many of them and the tyrants showed his hatred against them and plundered Mecca for three days and terrified its people severely. With what he did, he was angry, isolated, and he was summoned to Egypt. He sent another prince to Mecca. In (631/ 1233), Sultan Nuruldin prepared funds and an army that was drawn to Sharif Rajih bin Qatada and was able to defeat the Ayyubid army and expel it from Mecca in (632 AH/ 1234). The kiswa of the Kaaba arrived from Baghdad. Sultan Nuruldin sent to Mecca, with gold and silver lanterns for the glorified Kaaba. He sent huge sums of money to the Sharif Rajih bin Qatada and ordered him to prepare to confront the army coming from Egypt to Mecca. When the Ayyubid army, led by Gabriel, arrived in Mecca, the Sharif was not ready to confront it. So, he left. The Sharif was likely to go to Yemen. So, the Ayyubid army entered Mecca in five hundred knights and settled there. Therefore, Sultan Nuruldin prepared an army from Yemen led by Shihab al-Din bin Idan in (633 AH/ 1235) and sent money to Sharif Rajih bin Qatada and ordered him to prepare an army. When the Yemeni army became close to Mecca, the Ayyubid army went out to them. They met in a place called Al-Kharifain between Makah and Al-Sarin. So, the Yemeni army was defeated. So. Prince Gabriel sent him to Egypt. In (635/1237), Sultan Nuruldin left. He meant Mecca with a thousand knights. He released for every soldier from the Ayyubid army who was in Mecca a thousand dinars, a horse, and a clothing. Many soldiers leaned to him. Then, the Sharif Rajih bin Qatada ordered to join him outside Mecca. There were three hundred of his followers with him. Then, he advanced to Mecca. When the Ayyubid prince Gabriel knew of that, he burned what was with him from the supplies and withdrew towards the Egyptian lands. Sultan Nuruldin marched to Mecca and entered it performing Umrah. When Sultan Nuruldin entered Mecca, he spent on his army and gave large sums of money and assigned Ibn Al-Waleedi and Ibn Al-Ta'iz to be the leaders of the army with 150 knights for each. So, they resided in Makah.

In (636 AH/ 1238), Sultan Nuruldin returned from Mecca to Yemen. In (637 AH/ 1239), Prince Senja, the Prince of Medina arrived in Mecca with a thousand knights and took control over it after the withdrawal of the army and the worker of Sultan Nuruldin from it. When Sultan Nuruldin knew of that, he prepared an army for Ibn al-Basri and al-Sharif Rajeh to Mecca. When the Sharif Sanja and his companions heard about them, they left Mecca and fled. Sanja went to Egypt to seek help from its sultan, the righteous King Najm alDin Ayyub al-Malik al-Kamil. So, he prepared an army for him. That army was able to reach Makah and enter it in $638 \mathrm{AH} /$ 1240). When Sultan Nuruldin heard of that, he prepared a large army to Mecca with Sharif Ali bin Qatada. When the Ayyubids in Hejaz knew of that, they wrote to Egypt asking for help. He sent them a hundred and fifty knights under the leadership of Prince Mubariz al-Din Ali bin Al-Hussein bin Bartas. When Sharif Ali Ibn Qatada knew of their arrival, he resided in Al-Sarrin. He sent to Sultan Nuruldin to inform him of that. Sultan Nuruldin went out to Mecca with a large army. When he reached Hejaz, the Ayyubids fled from it. Sultan Nuruldin entered Mecca and fasted there in the month of Ramadan in (639 AH/ 1240). Prince Mubariz al-Din Ali bin Al-Hussein arrived with several of his cousins and his companions willing to serve the Sultan. Sultan Nurulddin blessed them and clothed them all. Sultan Nuruldin suspended all taxes from Mecca, including taxes, levies, and grievances in Mecca. Sultan Nuruldin returned to Yemen in (640 AH/ 1241) in which the pilgrims of Iraq arrived in Mecca after having been cut off for Seven years from Mecca in (632 AH/ 1234). When the prince of the Iraqi Hajj arrived in Mecca, he covered the house and gave a large charity in Mecca. It seems that the mother of al-Mustasim al-Abbasi, along with al-Duwidar, the prince of the Iraqi Hajj, arrived in Mecca in (641 AH/ 1242) for the Hajj and made 60000 dinars charity. During the reign of Fakhr alDin al-Salakh, which lasted for seven years, Hejaz witnessed an economic recovery. Houses were built and the prices of foodstuffs decreased. In (646 AH/ 1248), Sultan Nuruldin isolated the prince Fakhr al-Din al-Salakh from Mecca. When Sharif Abu Saad knew about these measures, he attacked him and took what he had of horses and Mamelukes and bound him for fear of his escape with the money to Iraq. In (649 AH/ 1251), the covering of the Ka'ba arrived. In (651 AH/ 1253), Prince Abu Saad, the prince of Medina, was in his home, so 
he made a pilgrimage to the people of Medina and he resided in Makah. In (652 AH/ 1254), Rajahand Abu Nami Muhammad bin Abi Saad bin Ali bin Qatada and Idris ibn Qatada attacked Mecca and they removed Sharif Hammad bin Hassan From Mecca. Rajeh took over it for three months. Then, he was removed by his son Ghanem. He stayed there until Shawwal. Abu Nama Muhammad and Idris removed him from it. They stayed there in the month of Shawwal. Prince Mubariz al-Din al-Husayn bin Ali bin Ratash arrived Mecca with a hundred knights and met Al-Ashraaf at the entrance to Mecca and defeated them and entered Makah. AlAshraf of Mecca gathered in (653 AH/ 1255) to confront Prince Mubariz al-Din al-Hussein bin Ali bin Ratas. They besieged him in Mecca and entered Mecca from the tops of the mountains and fought them in the center of Makah and defeated him. He was captured and ransomed himself with money and went out with his followers to Yemen. The delegation of Yemen, led by Al-Mudhaffar, arrived for Hajj in 659 AH/ 1260). Then, the honorable guardian Idris bin Qatada and Abu Nami bin Abi Saad bin Ali bin Qatada left from it, fearing alMudhaffar.

In $669 \mathrm{AH} /$ 1270), Sharif Idris bin Qatada, the prince of Mecca, was killed. Abu Nami Muhammad bin Abi Saad bin Ali bin Qatada succeeded him until his death in (701 AH/ 1271). He had more than twenty children. His children were separated after him. Among them are Rumaitha, Humaydah, Abi Al-Ghaith and Atifa.

It seems that the conflict in Hejaz continued between the offspring of Banu Qatada until the end of their state for the sake of power. Some of them were seeking help from Egypt and some from Yemen.

\section{CONCLUSIONS}

1. When the caliphate was transferred to the Umayyad state in $41 \mathrm{AH} / 661$ ), Hejaz became a region that is directly linked to the state. Hejaz was divided into three administrative regions, the centers of which are Medina, Makah, and Taif. Makah and Taif were sometimes gathered for the governor of Medina and sometimes, each one has an administrative governor. Medina remained the center of the state of Hejaz in the Umayyad era except the era of Abdullah bin Al-Zubair (64-73 AH/ 683-692). He took Mecca as a center for his ruling.

2. The status of Hejaz did not differ after the transfer of the caliphate to the Abbasids and the transfer of the center of ruling To Baghdad in Iraq. Hejaz remained a region that is linked to the capital Baghdad. The governors were sent to it from the princes of the Abbasids or from those who are closely related to the Abbasids. During the era of some of them, they gathered Hejaz and Yemen in one state centered in Mecca. The governor of Hejaz appointed a representative for him in Yemen.

3. Al-Ashraf declared their emirate in Hejaz in (359 AH/ 969). The Prince Jaafar bin Muhammad was considered the first prince of Hassanis.

4. Competition became obvious between the Abbasid state and the Fatimid state over the subordination of Hejaz and the establishment of the sermon for them in Mecca because it represents their sovereignty and legitimacy over the Islamic world.

5. Sharif Abu Al-Fotouh Al-Hassan bin Jaafar declared himself the Caliph, entitled himself Al-Rashid, and departed from obedience to the Fatimid state.

6. Muhammad Ibn Ja'far added "Hayya Ala Khair Alamal: Good deeds are recommended" to the Athan. It seems that he wanted to win the friendship of the Fatimid state.

7. Some of the noble princes used a new method to satisfy the Abbasid and Fatimid states. So, they established the sermon for the Abbasid state while preserving its relationship with the Fatimid state by keeping the phrase (Good deeds are recommended) in Athan.

\section{REFERENCES}

Ibn Al-Diba , A. Bughyat Almustafeed fi akhbar madinat Al-Zabid.

Ibn Al-Dibaa, A. Qurat al-Ayyun fi akhbar Al-Yemen Almaimoon.

Idris, E. (1984). Ayoun Al Akhbar wa funoon Al-Athar, 2nd edition, Reviewed by: Mustafa Ghaleb, Dar Al Andalus, Beirut.

Al-Baghdadi, A. The Difference Between classes, Al-Madani Press, Cairo.

Al-Ahdal, A. (2004). Tuhaf alzaman fi tareekh sadat Al-Yaman, Reviewed by: Abdullah Muhammad, The Cultural Foundation, Abu Dhabi. 
Al-Jundi, M. (1995). Al-Sulook fi tabakat alolamaa walmulook, 2nd edition, Reviewed by: Muhammad Bin Ali Bin Al-Hussein Al-Akwa, Publishing House, Al-Irshad Library, Sana'a.

Al-Haridhi, Y. (1985). Ghirbal Al-Zaman fi wafiat al-aayan, Reviewed by: Muhammad Naji, Zaid bin Thabit Press, Damascus.

Al-Husseini, M. Anbaa Al-Zaman fi akhbar Al-Yemen from 280 to 322 AH, Reviewed by: Muhammad Abdullah Madi, Religious Culture Library.

Al-Khazraji, A. (1983 ). Al-Okood Al-Lulua fi aldawla alrassoolia, Reviewed by: Muhammad bin Ali al-Akwa alHawali, Yemeni Studies and Research Center, Sana'a.

Ibn al-Diba, A. (1983). Al-Mazid fi akhbar madinat al-Zabid, Reviewed by: Yousuf Shalhad, Dar Al-Ood, Beirut.

Ibn Saad, A. (1410 AH ). Al-tabakat al-kubra, Reviewed by: Muhammad Abdulqadir Atta, Dar Al-Kutub AlUlmiyyah, Beirut.

Al-Shirazi, I. (1970). Tabaqat al-Faqih, Reviewed by: Ihssan Abbas, Dar Al-Raed Al-Arabi, Beirut, Lebanon.

Al-Safadi, S. (2000). al-Wafi fi alwafiat, Reviewed by: Ahmed al-Arnaout and Turki Mustafa, House of Revival of Heritage, Beirut.

Ibn Abd al-Barr, Y. (1412 AH). Al-Isteeaab fi ma'arifat al-ashab, Reviewed by: Ali Muhammad al-Bajawi, Dar Al-Jeel, Beirut.

Ibn Abdulmajeed, T. (1985). Bahjat Al-Zaman fi tareekh Al-Yaman, $2^{\text {nd }}$ edition, Reviewed by: Mustafa Hejazi, Dar al-Kalima, Sanaa.

Ibn Asakir, A. (1415 AH). History of Damascus, Reviewed by: Amr Ibn Thameia, Dar Al-Fikr for Printing, Publishing and Distribution.

Ibn Ali, Y. (1968). Ghayat Al-Amani fi Akhbar Al-Qutr Al-Yamani, Reviewed by: Saeed Abdulfattah Ashour, Dar Al-Arabi Writer, Cairo.

Al-Malik Al-Ashraf, I. (1975). Al-Asjad Al-Masbook wal-jawhar al-mahkook fi tabakat al-khulafaa wal-mulook, Reviewed by: Shakir Abdulmuneim, Dar Al-Bayan, Baghdad.

Al-Hamdani, A. (1884). Sifat Al-Jazeera Al-Arabia, Braille Press, Leiden.

Al-Yafie, A. (1997). Mirraat Al-Jinan waibrat al-yaqdhan fima yu'tabar min hawadith al-zaman, Reviewed by: Khaleel Al-Mansour, Dar Al-Kutub Al-Ilmiyya, Beirut, Lebanon. 